\title{
Ecological Boundaries and Interference with the Global Nitrogen Cycle: A Review on Soil Nitrogen Management Strategies
}

\author{
R.N.N. Perera ${ }^{1}$ and B. Maharjan ${ }^{2 *}$
}

Date Received: $28^{\text {th }}$ April 2020 / Date Accepted: $30^{\text {th }}$ September 2020

\begin{abstract}
Purpose : Nitrogen (N) fertilizer is a major input in agro-ecosystems and has health, economic, and environmental implications. Changes in the global $N$ cycle has transgressed the ecological safe boundary at present. Therefore, sustainable soil $N$ management tools should be identified and implemented to reduce environmental implications of agriculture. This review paper intends to describe the magnitude of the global $N$ based pollution, its health, economic, and environmental implications and suggest for approaches to achieve sustainable soil $N$ management.
\end{abstract}

Research Method: This paper shares a literature review on current efforts in optimizing soil $N$ management. The central topic is an on-farm experiment conducted in the University of Nebraska-Lincoln, USA that monitors and manages in-season $N$ in maize using a crop sensor technology. Other reliable findings from previously conducted studies worldwide are presented as well.

Findings : Results of field studies revealed that there were no significant variations in maize grain yields between sensor-based treatment and farmer's business-as-usual treatment However, the crop sensorbased treatment recorded savings of $N$ at an average rate of $32 \mathrm{~kg} / \mathrm{ha}$. Based on the reported findings in literature, advanced fertilizer technology, manipulation of fertilizer application methods and development of conceptual models to predict the crop $N$ need are other potential tools to optimize $N$ in agriculture.

Research Limitation: The behavior of reactive $N$ in soil is unpredictable due to a complex interacting effect of crop, soil, climatic and management factors.

Originality/ Value : In Sri Lanka as a country having a significant stake in agriculture, understanding and adoption of some of these available new technologies for efficient $N$ management will serve well in our efforts for ecological sustainability.

Keywords: Crop sensor, ecological safe boundary, fertilizer, reactive nitrogen, soil

\section{INTRODUCTION}

Since this earth is a finite system, it has its own limits. With the rapid expansion in global industrial sector developments, a subsequent transgression into planetary ecological boundaries is becoming a huge threat to the ecological balance. The concept of ecological safe boundaries was first proposed by the team of scientists from Australian National University in 2009. Nine planetary boundaries were identified and seven among them were quantified including climate change, biodiversity loss, interference with $\mathrm{N}$ and $\mathrm{P}$ cycle (biogeochemical $\mathrm{N}$ and $\mathrm{P}$ ), global freshwater use, ocean acidification, ozone depletion, and land use. Amongst the nine, atmospheric aerosols and chemical pollution are to be quantified. Further, the boundaries of climate change, loss of biodiversity and

\footnotetext{
1 Department of Export Agriculture, Faculty of Agricultural Sciences, Sabaragamuwa University of Sri Lanka, 70140, Sri Lanka

$2^{2 *}$ Department of Agronomy and Horticulture, University of Nebraska-Lincoln, NE 685830915,USA

bmaharjan@unl.edu
}

(D) http://orcid.org/0000-0002-4728-7956 
changes to global $\mathrm{N}$ cycle have already been transgressed by the human activities on this planet (Rockstrom, et al., 2009, Steffen, et al., 2015). Ecological safe boundaries demarcate the safe zone for anthropogenic activities while achieving global sustainable goals (Table 01). When the planet is transitioned from Holocene to the Anthropocene, these unacceptable changes were created with increasing man-made activities. Exponential growth of human activities due to industrialization and agriculture continuously change the earth system into an unknown state where it can cause catastrophic disasters for the human well-being.
As far as agricultural activities are concerned, soil nutrient management plays a role of paramount importance. With the intensification of cropping systems, rapid surge of synthetic fertilizers and other agrochemicals are becoming prominent thus challenging both soil health and the health of all living beings. Majority of farming systems primarily focus on soil fertility and the crop productivity. However, advances in ecology and climate science have intensified calls for sustainable practices in all spheres of human activities including agriculture.

Table 01: Global Planetary Boundaries (Line 100-102)

\begin{tabular}{|c|c|c|c|c|}
\hline \multicolumn{5}{|c|}{ Planetary Boundaries } \\
\hline $\begin{array}{l}\text { Earth-system } \\
\text { process }\end{array}$ & Control variable & $\begin{array}{c}\text { Boundary } \\
\text { value }\end{array}$ & $\begin{array}{l}\text { Current } \\
\text { value }\end{array}$ & $\begin{array}{c}\text { Boundary } \\
\text { across status }\end{array}$ \\
\hline \multirow{2}{*}{$\begin{array}{l}\text { Climate } \\
\text { change }\end{array}$} & $\begin{array}{l}\text { Atmospheric carbon dioxide concentration } \\
\text { (ppm by volume) }\end{array}$ & 350 & 400 & Yes \\
\hline & $\begin{array}{l}\text { Increase in radiative forcing }\left(\mathrm{W} / \mathrm{m}^{2}\right) \text { since } \\
\text { starting industrial revolution }(\sim 1750)\end{array}$ & 1 & 3.101 & Yes \\
\hline \multirow[t]{2}{*}{$\begin{array}{l}\text { Biodiversity } \\
\text { loss }\end{array}$} & $\begin{array}{l}\text { Extinction rate (number of species per million } \\
\text { per year) }\end{array}$ & 10 & $>100$ & Yes \\
\hline & $\begin{array}{l}\text { Anthropogenic nitrogen removed from the } \\
\text { atmosphere (millions of tons per year) }\end{array}$ & 35 & 121 & Yes \\
\hline $\begin{array}{l}\text { Interference } \\
\text { with } \mathrm{N} \text { and } \mathrm{P} \\
\text { cycle }\end{array}$ & $\begin{array}{l}\text { Anthropogenic phosphorus going into the } \\
\text { oceans (millions of tons per year) }\end{array}$ & 11 & $8.5-9.5$ & No \\
\hline $\begin{array}{l}\text { Global } \\
\text { freshwater } \\
\text { use }\end{array}$ & Global human consumption of water $\left(\mathrm{km}^{3} / \mathrm{yr}\right)$ & 4000 & 2600 & No \\
\hline $\begin{array}{c}\text { Ocean } \\
\text { acidification }\end{array}$ & $\begin{array}{l}\text { Global mean saturation state of calcium } \\
\text { carbonate in surface seawater (omega units) }\end{array}$ & 2.75 & 2.90 & No \\
\hline $\begin{array}{l}\text { Ozone } \\
\text { depletion }\end{array}$ & $\begin{array}{l}\text { Stratospheric ozone concentration (Dobson } \\
\text { units) }\end{array}$ & 276 & 283 & No \\
\hline Land use & Land surface converted to cropland (percent) & 15 & 11.7 & No \\
\hline
\end{tabular}




\section{Reactive N in Agriculture}

Agricultural activities, fossil fuel combustion, and other human activities have altered the global N cycle substantially, generally increasing both the availability and the mobility of $\mathrm{N}$ over large geographical regions of Earth. Moreover, many of the mobile forms of $\mathrm{N}$ themselves have environmental consequences. Although most $\mathrm{N}$ inputs provide human needs such as agricultural production, their environmental consequences are serious and long term (Vitousek, 1997). It is an obvious fact that use of $\mathrm{N}$ in farming activities has tremendously increased with the green revolution in 1960's with the yields of crops as well. Increased use of $\mathrm{N}$ in agriculture and soil degradation and erosion due to agricultural intensification are becoming the major sources of nutrient pollution in receiving ecosystems downstream. Nitrogen naturally occurs in the atmosphere in the form of diatomic gas $\left(\mathrm{N}_{2}\right)$ and different forms of $\mathrm{N}$ such as oxide gasses $\left(\mathrm{NO}_{2}, \mathrm{~N}_{2} \mathrm{O}, \mathrm{NO}\right)$. Amine derivatives $\left(\mathrm{NH}_{3} \mathrm{NH}^{+}\right)$, nitrous oxide $\left(\mathrm{N}_{2} \mathrm{O}\right)$, and anions $\left(\mathrm{NO}_{2}^{-}, \mathrm{NO}_{3}^{-}\right)$ are considered as reactive $\mathrm{N}$ which supports growth of life forms by converting into proteins directly or indirectly. As humans learned to break down $\mathrm{N}_{2}$ and form reactive $\mathrm{N}$ via Haber-Bosch process, all possible forms of reactive $\mathrm{N}$ cascade through various ecosystems that cause harm in the environment (Gerald, et. al., 2011). Most of these forms become available in high quantities in the environment due to mismanagement of fertilizer $\mathrm{N}$ in agriculture operations. Further, the burning of fossil fuels releases fixed $\mathrm{N}$ in the fuel and help in conversion of $\mathrm{N}_{2}$ to $\mathrm{NH}_{3}$. The release of $\mathrm{N}$ from biological pools such as clearing forested land also contributes to reactive $\mathrm{N}$ in the environment (Kanter and Searchinger, 2018; Vitousek, 1997). Therefore, an integrated approach needs to be adopted in solving $\mathrm{N}$ related issues in the environment. The objective of this review paper is to discuss agricultural $\mathrm{N}$ management with associated negative impacts in ecology and identify available technology and tools to optimize $\mathrm{N}$ management with reduced environmental implications.

\section{Importance of Reactive $N$ in Food Production}

Considering the terrestrial ecosystems, $\mathrm{NH}_{4}^{+}$and $\mathrm{NO}_{3}{ }^{-}$are considered as the most abundant form of reactive $\mathrm{N}$ in soil solution and on exchange complex. Plant roots uptake $\mathrm{N}$ in these forms for its growth and grain production. Relative presence of these compounds is mainly governed by other chemical, physical and biological properties and conditions of the soil and considered as an integrated system. In a given time, concentration of these ionic forms in the soil solution is less due to continuous uptake by plant roots and slower release by mineralization of N-rich organic matter. These diminishing amounts are constantly being replenished by adding $\mathrm{N}$ based fertilizer to the soil.

\section{Environmental Implications of $N$}

Ammonium based $\mathrm{N}$ is readily adsorbed on soil exchange complexes and does not move down the profile in larger amounts like nitrate-N. However, it gets converted to $\mathrm{NH}_{3}$ gas if along with high soil $\mathrm{pH}$, soil surface gets dry and weather is windy. Nitrate based $\mathrm{N}$ in the soil solution can be lost easily from the root zone via leaching when water percolates down the soil profile and reaches natural water bodies.

Nitrate- $\mathrm{N}$ is also denitrified to $\mathrm{N}_{2} \mathrm{O}, \mathrm{NO}_{2}$ and $\mathrm{N}_{2}$ if anaerobic conditions occur in the soil and there is a sufficient supply of $\mathrm{C}$ to denitrifiers (Bijay and Singh, 2003). In the case of Sri Lankan agriculture, urea is a major source of $\mathrm{N}$ used for many cropping systems where its fertilizer use efficiency lies maximum around 30\%. Most of the remaining $70 \%$ of applied $\mathrm{N}$ is prone to loss due to less adherence of $\mathrm{NO}_{3}-$ on soil colloids and subsequent leaching. Therefore, $\mathrm{NO}_{3}{ }^{-}$could be considered as the major factor for many $\mathrm{N}$ related negative consequences from agricultural soil locally and globally polluting specifically the water bodies. 


\section{Ground water contamination and related issues;}

Nitrate- $\mathrm{N}$ is readily soluble in water and can be lost via run off or leaching to water system downstream and thus contaminate ground water and other water bodies. Increased levels of nitrates in ground water directly increase the risk of many health issues including blue baby syndrome and carcinogenic effects. The World health Organizatio (WHO) has established maximum contaminant limit of Nitrate per liter of water as $50 \mathrm{mg}$. Excess amounts of reactive $\mathrm{N}$ including majority of nitrates in water bodies cause eutrophication leading to algal blooms in lakes and marine areas. This affects negatively on entire aquatic ecosystems. Nitrate in water also contributes to global climate problems as nitrate converts to nitrous oxide, a potent greenhouse gas (GHG).

\section{Contribution for GHG emission, global warming and climate change;}

Nitrous oxide $\left(\mathrm{N}_{2} \mathrm{O}\right)$, is a greenhouse gas that also contributes to stratospheric ozone depletion (EPA, 2010). On a molecule for molecule basis, $\mathrm{N}_{2} \mathrm{O}$ has a global warming potential about 300 times greater than that of $\mathrm{CO}_{2}$ (Prather et al., 2001).

\section{Disturbances to the process of soil natural $N$ fixation;}

Excess reactive $\mathrm{N}$ in the soil would become toxic to naturally present $\mathrm{N}$ fixing microorganisms in the soil and the process of natural $\mathrm{N}$ fixation and other soil biological reactions such as denitrification, nutrient metabolism etc. become diminished over time. Surge of $\mathrm{CO}_{2}$ concentration in the atmosphere and changes in the $\mathrm{N}$ deposition can interfere with the natural $\mathrm{N}$ fixation process in the soil (Reed et al., 2011). Findings of a research experiment in Eastern United States showed that the elevated $\mathrm{CO}_{2}$ and artificial $\mathrm{N}$ fertilization treatment had a strong and suppressive impact on soil $\mathrm{N}$ fixation (Sean et al., 2014).

\section{Non-protein $N$ accumulation and depletion of chemotherapeutic chemicals in food;}

This concerns a serious health issue for both human and livestock. Increased use of $\mathrm{N}$ fertilizer and high $\mathrm{N}$ intake by plants lead to accumulation of non-protein $\mathrm{N}$ in plant tissues. This is mainly due to lack of enough time to convert non-protein $\mathrm{N}$ by metabolic functions into plant protein as a result of frequent uptake of fertilizer. Therefore, food crops produced by adding synthetic fertilizers may not be as healthy and nutritious as they should be. Studies showed that high levels of $\mathrm{N}$ availability in plant tissues influence negatively on total antioxidant activity in plants (Elhanafi et al., 2019, Nguyen, P., and Niemeyer, E.D., 2008). Antioxidants are considered as the main chemotherapeutic chemicals derived from plants and polyphenols (phenolic acids, flavonoids, anthocyanins, lignans and stilbenes), carotenoids (xanthophylls and carotenes) and vitamin $\mathrm{C}$ and $\mathrm{E}$ are the key examples. Especially polyphenols and carotenoids are enriched with anti-inflammatory, anti-microbial, anti-aging and anti-cancer properties in human. Increased availability of $\mathrm{N}$ within the plant may make it less healthy for consumption (Xu et al., 2017).

\section{High vulnerability of crops for pests and diseases;}

Growth and development of plants, insect pests and disease-causing agents are favored by mineral nutrition. Large canopies with dense shoot growth are conducive for spore deposition and development of fungal pathogens such as Magnaporthe griceae, Oidium lycopersicum and Pseudomonas syringae. Studies also showed that manipulation of $\mathrm{N}$ levels on the crop could be utilized as a disease management tool. High levels of $\mathrm{N}$, especially ammonium, are toxic to some plants and moderately high levels promote lush vegetative growth that is susceptible to pests and diseases (Parthasarathy, 2015). In addition, some studies showed that pests lay more eggs in chemically $\mathrm{N}$ treated plots compared to organically grown plants (National Institute of Food and Agriculture, USA). Plants inherently have their own chemical and structural defense mechanisms against pests and disease attacks. 
Increased availability of $\mathrm{N}$ for plants leads to reduction of these self-defense mechanisms. Studies showed that this increased susceptibility to pests and diseases is mainly due to more nutrients availability to pathogens and pests as well as suppression of bio synthesis of antimicrobial substances against pathogens (Guo et al., 2010; Ju et al., 2009; Liu et al., 2013).

\section{Deployment of crop sensor technology in sustainable $N$ application}

The use of crop sensing technology in grains, cereals and other crops is a novel technique to increase plant health and yield potential. This enables in-season monitoring of the crop during the growing season and can help producers to determine actual $\mathrm{N}$ needs and timing of applications. This intensive management can help producers match $\mathrm{N}$ input to yield potential during the season (Chua et al., 2003). Light reflectance differs in healthy plants than stressed plants. When plants are subjected to any kind of stress like nutrient deficiency, drought, disease or pest attack, such plants will reflect less nearinfrared (NIR) and high amount of red light than healthy plants. The use of crop sensor enables a site-specific $\mathrm{N}$ management strategy along with assessing the yield potential of crops and would be an advantage in terms of profit for the business and environmental conservation. Fertilizer application as a blanket recommendation leads to low crop $\mathrm{N}$ use efficiency due to variability present in fields (Singh, 2017; Jain and Abrol, 2017). The greater the amount of soil variability, the harder it is for a producer to apply the correct amount of $\mathrm{N}$ for a specific part of the field (Scharf et al., 2002).

Crop sensors are designed to measure the ratio between the amounts of absorbed and reflected specific wave lengths of light precisely. The numeric reflectance data are used to estimate vegetative indices. The Normalized Difference Vegetative Index (NDVI) is one of the most commonly used indices in crop sensing. The NDVI is highly correlated with the amount of green vegetation produced by plants. It is necessary to establish a reference strip with adequate $\mathrm{N}$ fertilizer applied at non-limiting amounts in a most representing area of the cultivated land. These strips can be monitored throughout the growing season and compared to the rest of the field and resembles "farmer practice". Crop canopy sensor-based $\mathrm{N}$ management detects the actual $\mathrm{N}$ need of plants by combining spectral information with an algorithm that allows sitespecific $\mathrm{N}$ fertilization within a field. Some algorithms consider other factors such as soil moisture, growing degree days, and even crop growth characteristics such as plant height. It has been reported that $\mathrm{N}$-sensors are valuable for avoiding over- and under- fertilization within a field, resulting in increased yield, decreased lodging, and more homogenous ripening (Lammel et al., 2001).

\section{DISCUSSION}

In the United States, there are 2.1 million farms spread over approximately 33 million hectares of land (Kanter and Searchinger, 2018). The use of crop sensors, combined with reference strips in experimented sites, has recorded savings of USD 24-48 per hectare in $\mathrm{N}$ fertilizer costs as well as increased $\mathrm{N}$ use efficiency (Olga, 2015, Olga et al., 2018). Another study conducted at 55 sites in Missouri, USA has compared sensor determined $\mathrm{N}$ rates to farmer determined $\mathrm{N}$ rates. The study found that utilization of crop sensors reduced the amount of $\mathrm{N}$ that was applied by $15.69 \mathrm{~kg} / \mathrm{ha}$ and increased the profit by $\$ 40.8 /$ ha averaged over all locations. This increase in profit was due to reduced $\mathrm{N}$ use and increased crop yield. Despite the benefits of sensors for $\mathrm{N}$ management, less adoption of farmers to the technology due to high initial cost is a challenge (Scharf et al., 2011). Results of multi-site study which were conducted in Nebraska, USA in 2015-2017 and compared grower practice and use of crop sense for $\mathrm{N}$ management in maize are summarized in the table 02 . 
Table 02: $\quad$ Comparison between crop sense and grower standard $\mathrm{N}$ application (Line 264-272)

\begin{tabular}{ccc}
\hline 2015-2017 Average & Crop Sense & Grower \\
\hline Total N rate (kg N/ha) & 180.4 & 212.6 \\
Maize yield (Mg/ha) & 13.7 & 13.8 \\
Partial Factor Productivity (kg grain/kg N) & 83 & 68 \\
Partial profitability (USD/ha) & 692.8 & 679.6 \\
\hline
\end{tabular}

Source: Project Sense, university of Nebraska-Lincoln, 2019

This multi-site/multi-year study from Nebraska showed that there were no significant differences in grain yield between sensor-based treatment and farmers' management treatment. However, the sensor-based treatment recorded savings of $32.2 \mathrm{~kg} \mathrm{~N} / \mathrm{ha}$ and thereby, enhanced crop N use efficiency and profitability (Project SENSE, UNL, 2019). Another study conducted in North China (Cao et al., 2016) compared three inseason $\mathrm{N}$ management strategies that included ACS; active crop canopy sensor, and soil $\mathrm{N}$ test based in-season $\mathrm{N}$ management strategy (20092013) against farmer's conventional practice with blanket recommendation. Results revealed that the ACS significantly improved the estimation of early season precision $\mathrm{N}$ management and the grain yield of winter wheat. Further, both in- season $\mathrm{N}$ management strategies significantly reduced the rate of $\mathrm{N}$ application compared to farmer's practice. However, there was not any significant difference in grain yield among all three $\mathrm{N}$ management methods (Cao et al., 2016).

\section{RECOMMENDATIONS}

Agricultural operations could be considered as a major source in relation to the reactive $\mathrm{N}$ in the environment, Therefore, an approach which satisfies the needs of agriculture and producers without breaking the ecosystem balance would be of topical importance.

\section{Concern on actual crop $N$ need}

The amount of $\mathrm{N}$ being used by any crop at any time varies by crop growth stages. Soil and climatic conditions throughout the growing season influence how much $\mathrm{N}$ is available for the crop. It takes an extensive set of field trials data to model and determine how much $\mathrm{N}$ is needed for crop. For example, following is the model developed for $\mathrm{N}$ management in maize in Nebraska, USA.

Nitrogen needed $=$

$35+(1.2 \times$ Estimated yield $)-(8 \times$ nitrate $\mathrm{ppm})$ - (0.14 x Estimated Yield x \% Organic Matter $)$ - other credits (legumes, manure, and irrigation water nitrate).

Since N balance in agro-ecosystems is mainly governed by soil and climatic conditions, crop species, $\mathrm{N}$ fertilization rates, management practices, atmospheric $\mathrm{N}$ deposition, $\mathrm{N}$ content in irrigation water and losses, it is necessary to assess the residual $\mathrm{N}$ content in the soil and possible $\mathrm{N}$ mineralization. This enables adjusting $\mathrm{N}$ fertilizer application rates into an optimum utilizable level and minimize losses of $\mathrm{N}$ from soil (Sainju, 2017). Nitrogen balance in an ecosystem is measured by deducting $\mathrm{N}$ outputs and changes in soil total $\mathrm{N}$ storage from $\mathrm{N}$ inputs (Sainju, 2017) as shown below.

$$
\begin{aligned}
& \text { Nitrogen balance }=\mathrm{N} \text { inputs }-\mathrm{N} \\
& \text { outputs }- \text { changes in soil total } \mathrm{N}
\end{aligned}
$$

$\mathrm{N}$ inputs could be defined as inorganic and organic inputs of $\mathrm{N}, \mathrm{N}$ from biological fixation, atmospheric $\mathrm{N}$ deposition (rain, snow, dry deposition) irrigation water and content in the crop seed. Crop $\mathrm{N}$ removal, losses of $\mathrm{N}$ from soil (leaching, $\mathrm{NH}_{3}$ volatilization, gas emissions 
(NOx), denitrification, runoff, soil erosion, plant senescence) are considered as $\mathrm{N}$ outputs in an agro-ecosystem. Changes in total soil $\mathrm{N}$ is estimated by deducting total estimated soil $\mathrm{N}$ at the beginning of the considered period from total soil $\mathrm{N}$ at the end of the considered period (cropping season). Positive $\mathrm{N}$ balance as per this equation indicates that the system is gaining in $\mathrm{N}$ and in converse, a negative $\mathrm{N}$ balance represents $\mathrm{N}$ loss from the system. Since the $\mathrm{N}$ recycling does not occur in the soil efficiently due to various reasons, most of the time there may be a net gain or net loss of $\mathrm{N}$ from soil systems. Some parameters such as biological and atmospheric $\mathrm{N}$ deposition, $\mathrm{N}$ losses from various processors are practically difficult to precisely estimate, since these processors are largely uncertain and varying temporally and spatially. Multilevel-inferential modeling may guide decisions for site specific $\mathrm{N}$ fertilizer application with least environmental burden (Lv et al., 2015; Papadopoulos et al., 2017). Sri Lanka, as an agriculture-based country and having many environmental issues alongside in relation to agrochemical usage, developing tools to determine crop nutrient needs should be prioritized (Krienke et al., 2018).

\section{Utilizing available advanced fertilizer technology}

The advanced fertilizer technology focuses mainly on sustaining $\mathrm{N}$ availability in soil for crop use and reducing impact on environment. Available advanced fertilizer technologies include Enhanced Efficiency Fertilizers (EEF) in various ways to increase the $\mathrm{N}$ use efficiency by minimizing losses. Controlled release fertilizers through polymer coating (CRF) and fertilizers with urease and nitrification inhibitors are widely used in agriculture operations. Controlled released fertilizers release nutrients over an ample period of time and the releasing rate depends on root zone temperature, moisture, particle size and coating thickness. Currently, CRF is broadly used in agriculture worldwide. Fertilizer $\mathrm{N}$ is encapsulated and subjected to slow release enabling continuous nutrient release over growing season (50-80 days) to meet crop demand. In addition to $\mathrm{CRF}$, there are other formulations consisting of $\mathrm{N}$ transformation inhibiting additives. These inhibitors present within fertilizers manipulate the micro biota in soil such as Nitrosomonas and Nitrobactor which are responsible for converting $\mathrm{NH}_{4}^{+}$in soil to $\mathrm{NO}_{3}{ }^{-}$and helps to stay attach $\mathrm{N}_{\text {in }} \mathrm{NH}_{4}^{+}$form with soil colloids (Sempeho et al., 2014, Shaviv, 2018). Maize is the single largest agricultural $N$ consumer in US and in US maize belt, around $35 \%$ of lands exceeded the recommended $\mathrm{N}$ rate in 2016. A study was conducted to compare two scenarios of EFF increased usage in maize belt by 2030 and their effects on cost effectiveness, industry profitability and environment (Kanter and Searchinger, 2018). In scenario 1 where EEF use increases from $12 \%$ in 2016 to $30 \%$ in 2030, the avoided environmental damage due to reduced $\mathrm{N}$ losses will worth an average of USD 5 billion. In scenario 2 where EEF usage increases from $12 \%$ in 2016 to $50 \%$ in 2030 such avoided environmental damage will worth USD 8 billion.

\section{Manipulation of $N$ application methods}

4R Nutrient Stewardship principles promote the usage of right fertilizer source, at the right rate, at the right time, and in the right place. Following the 4Rs can help increase yields and profitability while protecting the environment and improving sustainability. Selection of correct type of fertilizer based on the specific crop type and crop characteristics ensures balanced supply of essential nutrients. Further, application of correct $\mathrm{N}$ source close to the crop for it to uptake, avoiding surface application of $\mathrm{N}$ fertilizer especially in dry conditions and high $\mathrm{pH}$ soils, increase use of cover crops to maintain nutrients in the root zone during non-cropping season may contribute towards a sustainable $\mathrm{N}$ management (Eagle et al., 2018). Reactive $\mathrm{N}$ in the environment is an emerging issue. Because of agriculture's dependence on $\mathrm{N}$ for continued yield improvements, it is an issue the industry will want to monitor and alleviate as the impact of reactive $\mathrm{N}$ in our environment is explored. All human activities on the planet must take the range within which Earth System processes varied in the Holocene as a scientific reference point for a desirable planetary state (Rockstorm et al., 2009). 


\section{CONCLUSION}

Accelerated human activities on the planet since pre-industrial era to present have resulted into transgressing three planetary boundaries, namely climate change, loss of biodiversity and interference with the $\mathrm{N}$ cycle. Although most $\mathrm{N}$ inputs serve human needs such as agricultural production, their environmental consequences are serious and long term. There is no easy solution for limiting $\mathrm{N}$ pollution in the agricultural systems across the world. This would become challenging with the growth of world population. Adopting new technology in $\mathrm{N}$ fertilizer management as active crop canopy sensor technology is promising towards reducing reactive $\mathrm{N}$ in the environment and related environmental consequences. Along with optical crop sensing, applying other techniques such as accounting for and minimizing $\mathrm{N}$ losses with $4 \mathrm{R}$ stewardship, determining actual and timely crop needs of nutrients by analyzing nutrient uptake by plants, soil $\mathrm{pH}$ and other soil properties and use of advanced fertilizer technology would improve the precision in agricultural operations. It is vital to popularize these technologies in agriculture based developing countries such as Sri Lanka to minimize the existing issues related to mismanagement of agrochemicals.

\section{Conflicts of Interest}

There is no conflict of interest to disclose under this study.

\section{REFERENCES}

Bijay, S., Singh, Y. (2017).Management and Use Efficiency of Fertilizer Nitrogen in Production of Cereals in India;Issues and Strategies, Journal of Indian Nitrogen management, 149-162. https:// doi.org/10.1016/B978-0-12-811836-8.00010-0

Bijay, S., Singh, Y. (2003). Nitrogen management in rice- wheat system in the Indo-Gangetic Plain; Nutrient management for sustainable rice-wheat cropping system, National Agricultural Technology Project, Indian Council of Agricultural Research. 99-114. https://doi. org/10.1007/978-1-4020-9875-8_10

Bijay, S., Sharma, R. K., Kaur, J., Jat, M. L., Martin, K. L., and Singh, Y. (2011). Assessment of the nitrogen management strategy using an optical sensor for irrigated wheat. Agronomy for Sustainable Development, 31(3): 589-603. DOI: 10.1007/s13593-011-0005-5

Cao, Q., Miao, Y., Li, F., Gao, X., Liu, B., Lu, D., and Chen, X. (2017). Developing a new Crop Circle active canopy sensorbased precision nitrogen management strategy for winter wheat in North China Plain. Precision Agric. 18:2-18. DOI: 10.1007/s11119-016-9456-7.

Chua, T.T., Bronson, K. F., Booker, J. D., Keeling, J. W., Mosier, A. R., Bordosky, J. P., Lascano, R. J., Green, C. J., and Segarra, E. (2003). In-season nitrogen status sensing in irrigated cotton: I. yields and nitrgen-15 recovery. Soil Science Society of America. 67(5): 1428-1438. https://www. researchgate.net/publication/288674713.18.03.2020. https://doi.org/10.2136/sssaj2003.1428

Eagle, A. J., Drury, C. F., Halvorson, A. D., Hoben, J. P., Maharjan, B., Parkin, T. B., Robertson, G. P., Smith, D. R., Venterea, R. T. (2018). Data for Fertilizer Management and Environmental Factors Drive N2O and NO3 Losses in Corn: A Meta-Analysis. Purdue University Research Repository. DOI: 10.4231/R7NS0S57.

Elhanafi, 1., Houhou, M., Rais, C., Mansouri, I., Elghadraoui, L., Greche, H. (2019). Impact of Excessive Nitrogen Fertilization on the Biochemical Quality, Phenolic Compounds, and Antioxidant Power of Sesamum indicum L Seeds. The Journal of food quality 2019:1-5. https:// doi.org/10.1155/2019/9428092 
Environmental Protection Agency report in USA. (EPA 2010). https:/www.epa.gov/sites/production/ files/2013-12/documents/annual-report-2010.pdf. 18.03.2020.

Environmental Protection Agency report in USA. (EPA 2012).https://www.epa.gov/sites/production/ files/2019-08/documents/2012-guidelines-water-reuse.pdf. 18.03.2020.

Gerald, M., and Rector, N. (2011). What is reactive N and why should I care. Michigan State UniversityExtension.https://www.canr.msu.edu/news/what_is_reactive_n_and_why_should_i care .25.2.2020.

Guo, J., H., Liu, X., J., Zhang, Y., Shen, J., L., Han, W., X., Zhang, W., F., Christie, P., Goulding, K., W., T., Vitousek, P., M., and Zhang1, F., S. (2010). Significant Acidification in Major Chinese Croplands. Science. 327 (5968): 1008-1010. DOI: 10.1126/science.1182570, 1008.

Jain, V., Abrol, P. (2017). Plant Nitrogen Use Efficiency, Journal of Indian Nitrogen Assessment. 163 175 :https://doi.org/10.1016/B978-0-12-811836-8.00011-2.

Jua, X., T., Xingb, G., X., Chena, X., p., Zhangb, S., L., Zhangc, L., J., Liua, X., J., Cuia, Z., L., Yinb, B., Christiea, P., Zhub, Z., L. and Zhanga, F., S. (2009). Reducing environmental risk by improving N management in intensive Chinese agricultural systems. PNAS.106 (9): 3041-3046 DOI: https://doi.org/10.1073/pnas.0813417106

Kanter, D., and Searchinger, T. D. (2018). A technology-forcing approach to reduce nitrogen pollution. Nature Sustainability.1: 544-550. DOI: 10.1038/s41893-018-0143-8.

Krienke, B., Dutcher, A., Ferguson, R., Irmak, S., Maharjan, B., Wortmann, C. S., and Yang, H. (2018). Consequences of fall-applied nitrogen. https://cropwatch.unl.edu/2018/consequencesfall-applied-n. 12.03.2020.

Lammel, J., Wollring, J. and Reusch, S. (2001). Tractor based remote sensing for varaible fertilizer application. Development in plant and soil sciences. 92. Springer, Dordrecht. DOI: https://doi. org/10.1007/0-306-47624-X_336.

Li, F., Y. Miao, F. Zhang, Z. Cui, R. Li, X. Chen, H. Zhang, J. Schroder, W. R. Raun, and L. Jia. 2009. In-season optical sensing improves nitrogen-use efficiency for winter wheat. Journal of Soil Science Society of America. 73(5):1566-1574. DOI: http://dx.doi.org/10.2136/sssaj2008.0150.

Liu, X., and Fusuo, Z. (2013). Nitrogen fertilizer induced greenhouse gas emissions in China. Environmental Sustainability. 3(5):407-413. DOI: 10.1016/j.cosust.2011.08.006.

Lv, S., Wand, X., and Liu, G. (2015). A Simple and Reasonable Calculation Equation of Balanced Fertilization. Journal of Agronomy. 5: 180-187. DOI: http://dx.doi.org doi: 10.3390/ agronomy5020180.

Nguyen, P., and Niemeyer, E.D. (2008). Effects of nitrogen fertilizarion on the phenolic composition and antioxidant properties of basil (Ocimum basilicum L.). The Journal of agricultural and food chemistry. DOI:http://10.1021.jf801485u.

Olga, S., w. (2015). Nitrogen Management in Field Crops with Reference Strips and Crop Sensors, https://www.researchgate.net/publication/284189780. 23.04.2020.

Olga S. W., Shafian, S., and Robin J. C. (2018). Evaluation of Sensor-Based Nitrogen Rates and Sources in Wheat. International Journal of Agronomy. 2018. DOI: https://doi.org/10.1155/2018/5670479 
Pajares, S., Brendan J. and Bohannan, J. (2016). Ecology of Nitrogen Fixing, Nitrifying, and Denitrifying Microorganisms in Tropical Forest Soils. Front Microbiol. 7. DOI: https://doi. org/10.3389/fmicb.2016.01045.

Papadopoulos, A., Kalivas, D. and Harzichristos, T. (2015). Site-Specific Multilevel Modeling of Potato Response to Nitrogen Fertilization. Sustainability. 7:6684-6705.DOI: https://doi. org/10.3390/su7066684.

Parthasarathy, S. (2015). Effect of fertilizers on plant diseases. http://agropedia.iitk.ac.in/content/ effect-fertilizers-plant-diseases. 18.3.2020.

Prather, M. J., Holmes, C. D. and Hsu, H. (2012). Reactive greenhouse gas scenarios: Systematic exploration of uncertainties and the role of atmospheric chemistry. Geographical Research letters. 39. DOI: https://doi.org/10.1029/2012GL051440.

Project Sense Report- UNL in 2019.https://cropwatch.unl.edu/projectsense. 19.01.2020.

Reed, S.C., Cleveland, C.C., Townsend, A.R. (2011). Functional ecology of free-living nitrogen fixation: a contemporary perspective, Annual Review of Ecology, Evolution and Systematics. 42:489-512. DOI: https://doi.org/10.1146/annrec-ecolsys-102710-145034.

Rockström, J., Steffen, W., Noone, K., Persson, A., Chapin, F.S., Lambin, E., Lenton, T. M., Scheffer, M., Folke, C., Schellnhuber, H., Nykvist, ., De Wit, C.A., Hughes, T., Leeuw, S. V.D., Rodhe, H., Sörlin, S., Snyder, P. K., Costanza, R., Svedin, U., Falkenmark, M., Karlberg, L., Corell, R.W., Fabry, V. J., Hansen, J., Walker, Liverman, D., Richardson, K., Crutzen, P. and Foley, J. (2009). Planetary boundaries: exploring the safe operating space for humanity. Ecology and Society. 14(2). DOI: https://doi.org/10.1038/461472a.

Sainju, U. M. (2017). Determination of nitrogen balance in agroecosystems. MethodsX. 4: 199-208. DOI: http://dx.dx.doi.org/10.1016/j.mex.2017.06.001.

Scharf, P. C., Schmidt, J. P., Kitchen, N. R., Sudduth, K. A., Hong, S. Y., Lory, J. A., and Davis, J. G. (2002). Remote sensing for nitrogen management. https://pdfs.semanticscholar. org/5513/8b91a9fe6bf475541e374500d218cfe4724f.pdf. 23.04.2020.

Scharf, P.C., Shannon, D. K., Palm, H. L., Sudduth, K. A., Drummond, S.T., Kitchen, N. R., Mueller, L. J., Hubbard, V. C. and Oliveira, L. F. (2011). Sensor-based nitrogen applications outperformed producer-chosen rates for corn in on-farm demonstrations. http:///Sensor_based Nitrogen_Applications_Out_performed_Producer_chosen_Rates_for_Corn_in_On_farm_ Demonstrations.pdf.24.01.2020. https://doi.org/10.2134/agronj2011.0164

Sean, T. B.T., Yeager, C. M., Laverne, G. G., Steven, B., Eichorst, S. A., Jackson, R. B. A., and Kuske, C. R. (2014).Nitrogen Fertilization Has a Stronger Effect on Soil Nitrogen-Fixing Bacterial Communities than Elevated Atmospheric $\mathrm{CO}_{2}$. Applied and Environmental Microbiology. 80(10): 3103-3112. DOI: doi: 10.1128/AEM.04034-13

Sempeho, S., TaikKim, H., Mubofu, E., and Hilonga, A. (2014). Meticulous Overview on the Controlled Release Fertilizers. Advances in Chemistry. DOI:http://dx.doi.org/10.1155/2014/363071.

Shaviv, A. (2018). Advances in controlled-release fertilizers. Advances in Agronomy. DOI: 10.1016/ S0065-2113(01)71011-5. 
Stevens, L.J. (2014). A regional investigation of in-season nitrogen requirements for maize using model and sensor-based recommendation approaches. M.S. thesis, Univ. Nebraska, Lincoln $\quad$.http://digitalcommons.unl.edu/agronhortdiss/73.16.01.2020. Steffen, W., Rockstrom, J., and Costanza, R. (2011). How defining planetary Bounderies can transform our approach to growth. https://www.researchgate.net/publication/229069964. 26.01.2020.

Vitousek , P. M., Aber, j. D., Howarth, R. W., Likens, G. E., Matson, P. A., Schindler, D. W., Schlesinger, W. H. and Tilman, D. G. (1997). Human alteration of the global Nitrogen cycle: source and consequences. DOI: https://doi.org/10.1890/1051-0761 (1997)007.

Xu, D. P., Li, Ya., Meng, X., Zhou, T., Zeng, J., Zhang, J. J. and Li, H. B. (2017). Natural Antioxidants in Foods and Medicinal Plants: Extraction, Assessment and Resources. International Journal of Molecular Science. 18 (1): 9.DOI: http://dx.doi.org/10.3390/ijms18010096. 